\title{
Çocuk Acil Servisine Göğüs Ağrısı Nedeniyle Bașvuran Hastaların Değerlendirilmesi
}

\author{
Murat Doğan*, Tuğçe Kalın, Utku Özer, Mehmet Adnan Öztürk
}

DOI: $10.17944 / m k u t f d .616945$

Murat Doğan: Uzm. Dr., Erciyes Üniversitesi Tıp Fakültesi Çocuk Sağlığı ve Hastalıkları, Çocuk Acil Bölümü, Kayseri

Email: doktormurat033@hotmail.com

ORCID iD: https://orcid.org/0000-0003-2954-3845

Tuğçe Kalın: Uzm. Dr., Erciyes Üniversitesi Tıp Fakültesi Çocuk Sağlığı ve Hastalıkları, Çocuk Acil Bölümü, Kayseri

Email: tugcekalindr@gmail.com

ORCID iD: https://orcid.org/0000-0003-2581-5639

Utku Özer: Uzm. Dr., Erciyes Üniversitesi Tıp Fakültesi Çocuk Sağlığı ve Hastalıkları, Çocuk Acil Bölümü, Kayseri

Email: dr.utkuozer@hotmail.com

ORCID iD: https://orcid.org/0000-0003-3669-8853

Mehmet Adnan Öztürk: Prof. Dr., Erciyes Üniversitesi Tıp Fakültesi Çocuk Sağlığı ve Hastalıkları, Cocuk Acil Bölümü, Kayseri Email: adozturk2000@yahoo.com ORCID iD: https://orcid.org/0000-0001-5397-1239

\section{Bildirimler/Acknowledgement}

* Sorumlu Yazar/Corresponding Author

\section{Çıkar Çatıșması/Conflict of Interest}

Yazarlar bu makale ile ilgili herhangi bir çıkar çatıșması bildirmemișlerdir.

The authors declare that they have no conflict of interests regarding content of this article.

Maddi Destek/Financial Support

Yazarlar bu makale ile ilgili herhangi bir finansal destek bildirmemișlerdir.

The Authors report no financial support regarding content of this article.

\section{Etik Beyan/Ethical Declaration}

Yazarlar, çalıșma için Erciyes Üniversitesi Klinik Araștırmalar Etik Kurulundan 18.04.2018 tarih ve 2018/222 karar sayı ile izin alındığını, çalıșmanın yürütülmesi esnasında Helsinki Beyannamesi 2013, ICJM tavsiyeleri ile COPE'un Editör ve Yazarlar için Uluslararası Standartlarının yanısıra ilgili diğer biyoetik kılavuzların dikkate alındığını beyan etmişlerdir.

Geliș/Received: 07.09.2019

Kabul/Accepted: 10.01.2020

e-ISSN: 2149-3103

Web: http://dergipark.gov.tr/mkutfd
Öz

Çocuk Acil Servisine Göğüs Ağrısı Nedeniyle Bașvuran Hastaların Değerlendirilmesi

Amaç: Çocuklarda göğüs ağrısı (GA) sık görülen ve aileleri oldukça huzursuz eden bir durumdur. Çoğu olguda organik bir patoloji bulunmamaktadır. Çalıșmamızda, göğüs ağrısı (GA) nedeniyle çocuk acil servisine bașvuran hastaların etyolojik nedenlerinin değerlendirilmesi amaçlanmıștır.

Gereç ve yöntem: Bu çalıșmada çocuk acil servisine GA șikayetiyle bașvuran olgular yaș, cinsiyet, mevsim, eșlik eden semptomlar, fizik muayene ve laboratuvar bulguları retrospektif olarak incelenmiștir.

Bulgular: GA șikayetiyle çocuk acil servisine bașvuran 5-18 yaș aralığındaki 330 hasta değerlendirildi. En fazla olgu 13 yașın üzerinde (n:183, \% 55,5) ve en az olgu da 8 yaș altındaydı (n:12,\% 3,6). GA olan kızların sayısı erkeklerden fazla olmasına rağmen istatistiksel olarak anlamlı değildi ( $p>0,005)$. GA'nın en sık nedenleri idiopatik (\% 57,9), kas-iskelet sistemi $(\% 14,5)$ ve solunum sistemi $(\% 10,3)$ olarak tespit edildi. Kardiyak nedenler \% 6,1 oranında tespit edilmiș olup en sık nedenleri mitral valv prolapsusu ve atrial septal defektti.

Sonuç: Çalıșmamızdaki GA'nın büyük bir bölümünü kalp dıșı nedenler olușturmaktadır. Kardiyak nedenli GA'nın hayatı tehdit eden sonuçları olabileceğinden dolayı ayıгıı tanı dikkatli bir șekilde yapılmalıdır. Ayrıntılı hikaye, fizik muayene ve laboratuvar tetkikleri sonucunda kardiyak patoloji düșünülmeyen veya bulunmayan hasta ve yakınlarına bilgi verilmesi ve onların rahatlatılması önem arz etmektedir.

Anahtar Kelimeler: Çocuk, Göğüs ağrısı, Kalp

\section{Abstract}

Evaluation of Patients Admitted to The Pediatric Emergency Department for Chest Pain

Aim: Chest Pain (CP) is a common problem in children which makes families anxious. Most cases do not have an organic pathology. In our study, it was aimed to evaluate the etiologic causes of patients admitted to the pediatric emergency department for chest pain.

Materials and Methods: Patients who presented to the pediatric emergency department due to CP were included. Epidemiological factors such as sex, age, season, accompanying symptoms, physical examination and laboratory findings were analyzed retrospectively.

Results: A total of 330 patients aged 5-18 years who were admitted to the pediatric emergency department with CP complaints were evaluated. The highest number of cases over the age of 13 years ( $\mathrm{n}: 183,55.5 \%$ ) and the least case was under 8 years of age ( $\mathrm{n}: 12,3,6 \%$ ). The female cases were more than the male cases, but the difference was not significant. The most common causes of CP were idiopathic (57.9\%), musculoskeletal system (14.5 \%) and respiratory system (10.3\%). Cardiac causes were detected with a rate of $6.1 \%$ and the most common causes were mitral valve prolapse and atrial septal defect.

Conclusion: According to our study, most of the $\mathrm{CP}$ in children is caused by non-cardiac causes. Because of cardiac CP may have life-threatening consequences, differential diagnosis should be made carefully. Information should be given to the patients and their relatives who are not considered or have no cardiac pathology as a result of detailed history, physical examination and laboratory tests. Relieving the concerns of the patients and their relatives is an important situation.

Keywords: Chest pain, Child, Heart

\section{GİRIŞ}

Göğüs ağrısı, çocuk acil servisine en sık başvuru sebeplerinden biridir (1). Çocuklardaki GA'nın en sık sebepleri idiopatik, kas-iskelet, solunum, gastrointestinal veya psikojenik olduğu belirlenmiştir. Kalp kökenli nedenler çok az olmakla birlikte kardiyak kökenli hastalıklar genelde ölümcül olduğu için aile ve çocuk çok endişeli olabilmektedir. Bu yüzden GA nedeninin kardiyak kökenli olup olmadığını hızlıca ayırt ederek tedaviye erken başlanılmalıdır (2). Bu çalışmada çocuk acil servisine GA şikayeti ile başvuran hastalar retrospektif olarak değerlendirilmiș ve ağrı nedenleri tartıșılmıștır. 
Tablo 1. Göğüs ağrısı ile çocuk acile başvuran hastaların demografik özellikleri

Sıklık (n) Yüzde (\%)

Cinsiyet

$\begin{array}{lcc}\text { Kız } & 178 & 53,9 \\ \text { Erkek } & 152 & 46,1\end{array}$

Yaş (yıl)

$\begin{array}{lrr}<8 & 12 & 3,6 \\ 8-13 & 135 & 40,9 \\ >13 & 183 & 55,5\end{array}$

Aile öyküsü

$\begin{array}{rrr}\text { Var } & 12 & 3,6 \\ \text { Yok } & 318 & 96,4\end{array}$

Şikayet

$$
\begin{aligned}
& \text { Göğüs ağrısı } \\
& \text { Göğüs ağrısı ve öksürük } \\
& \text { Göğüs ağrısı ve çarpıntı } \\
& \text { Göğüs ağrısı ve ağızda acı tat } \\
& \text { Göğüs ağrısı ve senkop }
\end{aligned}
$$

$\begin{array}{rr}241 & 73,0 \\ 41 & 12,4 \\ 33 & 10,0 \\ 9 & 2,7 \\ 6 & 1,8\end{array}$

Kardiyoloji konsültasyon

$$
\text { Evet }
$$$$
\text { Hayır }
$$

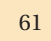

269

18,5

81,5

Akciğer grafisi bulguları
Normal

Pnömoni

Efüzyon

$301 \quad 91,2$

$26 \quad 7,9$

$3 \quad 0,9$

\section{GEREÇ VE YÖNTEM}

Bu çalışmada Erciyes Üniversitesi Tıp Fakültesi Çocuk Acil servisine Ocak-Aralık 2018 tarihleri arasında GA şikayetiyle başvuran 5-18 yaş aralığındaki 330 olgunun dosyası retrospektif olarak incelenmiştir. GA, göğüs veya abdominal boşlukta yer alan organlar ile göğüs duvarı veya sırt bölgesi kaynaklı hastalıklara eşlik edebilen, göğüste hissedilen hoş olmayan duygudur. "Akut gögüs ağrısı" 24 saat içerisinde ortaya çıkan yeni ve ani başlangıçlı, altta ksifoid, üstte suprasternal çentik ile iki orta aksiler hat arasında kalan bölgede hissedilen rahatsızlık hissi olarak tanımlanabilir. Dosyalar GA ile başvuran olgular yaşlarına göre 0-8, 8-13, 13-18 yaş olarak 3 gruba ayrıldı.

Hastaların dosyaları (yaş, cinsiyet, bulgular, aile öyküsü, mevsim, fizik muayene, laboratuvar sonuçları, elektrokardiyografi (EKG) ve yapılmışsa ekokardiyografi (EKO) bulguları) detaylıca incelendi. Solunum sistemi patolojisi düşünülen olgulardan akciğer grafisi, kardiyolojik patoloji düşünülenlerden de çocuk kardiyoloji konsültasyonu istenerek konsültasyon notu ve ekokardiyografi bilgiler kaydedildi. Kardiyak neden tespit edilen hastalar çocuk kardiyoloji bölümü tarafından takibe alınmışlardı. Tüm olguların troponin I, kreatin kinaz (CK) ve CK-MB değerleri vardı. Enfeksiyon (pnömoni, kostokondrit, miyozit vb) düşünülen vakalardan da sedimentasyon, tam kan sayımı, CRP değerleri istenmişti. Psikojenik olduğu düşünülen olgulardan çocuk psikiyatri konsültasyonu istenmiş gerekli görülenlere tedavi başlanmıştı. Çalışma öncesinde Erciyes Üniversitesi etik kurulundan onay alınmıştır. Çalışmada verilerin değerlendirilmesinde SPSS for Windows 18 proğramı kullanıldı. Tüm veriler ortalama ve yüzde (\%) değeri olarak hesaplandı. Kategorik değişkenler arası fark ki-kare testi kullanılarak değerlendirildi. $\mathrm{P}<0,05$ değeri istatistiksel olarak anlamlı kabul edildi.

\section{Etik Beyan}

Çalışma için Erciyes Üniversitesi Klinik Araştırmalar Etik Kurulundan 18.04.2018 tarih ve 2018/222 karar sayı ile izin alınmış, çalışmanın yürütülmesi esnasında Helsinki Beyannamesi 2013, ICJM tavsiyeleri ile COPE'un Editör ve Yazarlar için Uluslararası Standartlarının yanısıra ilgili diğer biyoetik kılavuzlar dikkate alınmıştır.

\section{BULGULAR}

Çalışmada değerlendirilen 330 hastanın \% 46,1'i erkek, \% 53,9'u kız cinsiyetteydi. Hastaların yaş aralığı 5-18 yıl idi. Hastaların \% 3,6'sı 8 yaş altında, \% 40,9'u 8-13 yaş aralığında ve \% 55,5'i 13 yaş üzerindeydi. Çalışma süresi boyunca hastanemize başvuran hasta sayısı 47147 olarak saptandı. Hastaların \% 96,4'ünün aile öyküsünde GA yoktu. Aile öyküsü pozitif olanlar ile kardiyak ve nonkardiyak GA nedenleri arasında anlamlı bir ilişki saptanmadı $(\mathrm{p}=0,06)$. GA'nın mevsimsel dağılımına bakıldığında sıklık sırasına göre kış, ilkbahar, yaz ve sonbahardı. Vakaların \% 73'ü sadece GA şikayetiyle başvurmuştu ve GA'ya eşlik eden semptomlar sırasıyla öksürük $41(\% 12,4)$ ), çarpıntı 33 (\% 10 ), gastrointestinal sistem semptomları 9 (\% 2,7), senkop $6(\% 1,8)$ olduğu görüldü. Hastaların hepsinin elektrokardiyografi (EKG) ve postero-anterior (PA) akciğer grafisi mevcuttu. Akciğer grafisinde iki yüz doksanbir hastanın (\% 91,2) akciğer grafisi normal olup, 3 (\%0.9 olguda plevral effüzyon, 26 (\% 7.9) olguda ise pnömonik infiltrasyon saptandı. 310 $(\% 93,9)$ hastanın EKG'si normal, 20 (\% 6,1) hastanın ise anormaldi. Anormal EKG bulguları ise ST elevasyonu 4, ST depresyonu 4, aritmi 9, T sivriliği 3 ve WPW (Wolf Parkinson White) sendromu ile uyumlu bulgular 2 hastada tespit edildi. Çocuk kardiyolojisi ile 61 hasta konsülte edildi ve yapılan ekokardiyografik değerlendirmede anormal bulgular 20 hastada mevcuttu (Tablo I). Bu patolojiler sıklık sırasına göre, MVP (Mitral Valv Prolapsusu), TY (Triküspit yetmezlik), ASD (Atrial Septal Defekt), MY (Mitral yetmezlik), 
WPW ve BAK (Biküspit Aort Kapağı) olarak saptandı (Tablo II). Kardiyak aile öyküsü ( \% 1,8 Miyokard İnfarktüsü, \% 1,8 Kalp Yetmezliği ) \% 3,6 sıklığındaydı. Tüm hastalardan kardiyak marker olan Troponin I bakılmış olup yalnızca bir hastanın değeri yüksek bulunmuştur. Kardiyak nedenli göğüs ağrıları erkeklerde kızlara göre daha sık olup, istatistiksel olarak anlamlı fark mevcuttu $(\mathrm{p}=0,002)$. Kardiyak ve nonkardiyak GA nedenleri ile yaş grupları ve mevsimler arasında anlamlı bir farklılık saptanmadı $(\mathrm{p}>0,005)$. Kardiyak ve nonkardiyak GA nedenleri ile CK, CKMB ve Troponin değerleri arasında istatistiksel olarak anlamlı bir farklılık saptanmadı ( $\mathrm{p}=0,63, \mathrm{p}=0,06, \mathrm{p}=0,065) .191$ hastada GA'ya neden olabilecek organik bir neden bulunamamış ve bu olgular idiyopatik GA olarak değerlendirilmiş. Tüm vakalar etyolojik açıdan değerlendirildiğinde organik ya da psikolojik neden bulunamayanlar idiyopatik olarak kabul edildi. İdiyopatik GA \% 57,9, kas-iskelet sistemine ait miyalji \% 5,4 , kostokondrit \% 9,1, solunum sistemine ait pnömoni $\% 9,1$, astım \% 1,2, endokrin sisteme ait hipertiroidi \% 1,2, gastrointestinal sisteme ait reflü $\% 2,7$, psikiyatrik sorunlar \% 3,6 ve diğerleri (migren, tonsillit vb) olarak tespit edildi (Tablo III).

\section{TARTIŞMA}

Göğüs ağrısı, çocuklarda ve özellikle adölesan yaş grubunda yaygın olan bir problemdir fakat erişkinlerdeki gibi kalp hastalıkları ile olan ilişkisi yok denecek kadar azdır (1). Ancak kardiyak kaynaklı GA ölümcül olabildiği için hekimleri, hastaları ve aileleri tedirgin etmektedir. Ayrıntılı anamnez ve iyi bir fizik muayene ile kardiyak nedenlerin ayırt edilmesi bu yüzden önem arz etmektedir. Kardiyak kaynaklı olduğu düşünülen olgularda ileri tetkik yapılmalıdır. GA ile ilgili yapılan çalışmalarda çocuk acil servisine başvuruların \% 0,7-\%5,2'sini GA oluşturmaktadır $(3,4)$. Bizim çalışmamızda da GA ile başvuran hastaların oranı $(\% 0,7)$ literatürle uyumlu şekildeydi.

Göğüs ağrısı erkeklerde daha sık görülmesine rağmen çalışmamızda kızlarda daha fazlaydı fakat istatistiksel olarak anlamlı değildi $(5,6)$. Kardiyak nedenli GA erkek cinsiyette daha fazlaydı ve istatistiksel olarak anlamlıydı ( $\mathrm{p}=0,002)$. Bu sonucu da sosyo-kültürel ve etnik farklılıklara göre GA nedenlerinin değişebileceğine bağlamaktayız. Pubertal çocuklarda GA'nın daha sık olduğu gösterilmiştir $(3,4,6)$. Bizim çalışmamızda da GA vakaları hem erkek hem de kız cinsiyette genelde pubertal yaş grubunda olduğu gösterilmiştir. Çalışmamızda GA ile yaş grupları ve cinsiyet arasındaki ilişkiye bakıldığında istatistiksel olarak anlamlı bir farklılık saptanmadı ( $>0,005)$. GA'nın mevsimsel dağılımına bakıldığında sıklık sırasına göre kış, ilkbahar, yaz ve sonbahardı. Kardiyak ve nonkardiyak GA nedenleri ile mevsim açısından anlamlı bir farklılık tespit edilmemiştir.

$\begin{array}{lcc}\text { Tablo 2. Kardiyak kökenli tanıların dağllımı } & \text { Yüzde (\%) } \\ \text { Sıklık (n) } & 30 \\ \text { Mitral valv prolapsusu } & 6 & 25 \\ \text { Atrial septal defekt } & 5 & 15 \\ \text { Triküspit yetersizlik } & 3 & 15 \\ \text { Mitral yetersizlik } & 3 & 10 \\ \text { Wolf Parkinson White } & 2 & 5 \\ \text { Biküspit Aort Kapağı } & 1 & 100 \\ \text { Toplam } & 20 & \end{array}$

Etyolojik nedenlerin tespiti için anamnezin ve fizik muayenenin ayrıntılı yapılması en önemli basamaktır. GA'nın sıklığı, süresi, başka semptomlar, gece-gündüz ilişkisi, eforla artıp artmadığı, travma öyküsü, yemeklerle ilişkisi gibi faktörler sorgulanarak doğru tanıya gidilmelidir. Fizik muayene kısmında akciğer ve kalp sesleri, gögüus cildinde hassasiyet, ağrı, şişlik, kızarıklık dikkatlice incelenerek gerekli görülürse pediatrik kardiyoloji konsültasyonu istenmelidir. Çünkü GA yapabilecek organik bir neden varsa fizik muayene genellikle normal değildir. Çocuklarda gözlenen GA'nın en sık sebepleri sırasiyla idiyopatik, solunum sistemi patolojileri, kas-iskelet sistemi hastalıkları, psikolojik hastalıklar, kardiyolojik hastalıklar ve diğer sebeplerdir $(1,2,7,8)$. İdiyopatik GA tanısı koyabilmek için ayrıntılı bir anamnez ve fizik muayeneden sonra gerekli görülen tetkikler (EKO, EKG, akciğer grafisi, troponin vb) yapılmalı ve GA'ya neden olabilecek organik sebepler ekarte edilmelidir. Günümüzde idiyopatik GA oranı \% 12-85 arasındadır ve idiyopatik GA spontan iyileşebilmektedir $(7,9,10)$. Bizim yaptığımız çalışmada da GA'nın en sık sebebi idiyopatikti ve literatürle benzer şekilde idiyopatik GA oranı \% 57,9 olarak tespit edilmiştir. GA'nın idiyopatik olduğu düşünülen hastalara ve ebeveynlerine ağrının kardiyak kaynaklı olmadığı anlatılmalı ve ailelerdeki tedirginlik bir an önce giderilmelidir. Çocuklarda sebebi belirlenmiş olan en sık GA nedenleri kas iskelet sisteminden kaynaklanmaktadır $(2,3,11)$. Bizim çalışmamızda da \% 14,5 oranı ile GA'ya sebep olan en sık ikinci neden olarak saptanmıştır. Kas iskelet sistemi nedenleri ise miyalj, miyozit, travma, kostokondrit, meme dokusu hassasiyetidir. Ayrıca ağır sportif faaliyet veya ağırlık kaldırma da sebep olabilir (7). Çalışmamızdaki kas iskelet sistemi kaynaklı GA nedenleri sırasıyla kostokondrit, miyalji ve miyozitti. Fizik muayenede göğüs bölgesinde palpasyonla hassasiyet varlığı, ağrı şiddetinin pozisyon ve soluk alıp verme ile değişiyor olması kas iskelet sisteminden kaynaklı GA'yı düşündürmelidir. Solunum sistemine bağlı pnömoni, astım, pnömotoraks, pulmoner emboli, plevral efüzyon gibi durumlar GA ile ortaya çıkabilir $(\% 12-21)(12,13)$. Çalışmamızda solunum sistemine ait GA'lar \% 10,3 oranında çıkmış olup sıklık sırası pnömoni, astım ve plevral efüzyondu. GA'ya ek olarak ateş, öksürük, anormal solunum bulgu- 


\begin{tabular}{lcc}
$\begin{array}{l}\text { Tablo 3. Göğüs ağrısı sebebiyle çocuk acil servise başvuran hastaların etyolojik } \\
\text { olarak değerlendirilmesi }\end{array}$ & Sıklık (n) \\
\hline & 191 & Yüzde (\%) \\
İdiyopatik & 30 & 57,9 \\
Kostokondrit & 30 & 9,1 \\
Pnömoni & 20 & 9,1 \\
Kardiyak & 18 & 6,1 \\
Miyalji & 12 & 5,4 \\
Psikojenik & 9 & 3,6 \\
Gastrointestinal & 4 & 2,7 \\
Astım & 4 & 1,2 \\
Tiroid & 12 & 1,2 \\
Diğer & 330 & 3,6 \\
Total &
\end{tabular}

su ve anormal akciğer sesleri durumunda akciğer grafisine bakılmalıdır.

Peptik ülser, özefajit, hiatal herni, gastroözefageal reflü, gastrit, pankreatit gibi gastrointestinal sistem (GİS) patolojileri de GA'ya sebep olabilir. GİS kaynaklı GA sıklıkla epigastrik ve substernal bölgelerde görülür. Ağızda acı tat hissi, gece öksürükleri, açlık-toklukla ve yemeklerle ilişkili olabilmektedir. Çalışmalarda GİS kaynaklı GA oranı \% 1,44,5 olarak tespit edilmiştir $(2,10,13)$. Bizim çalışmamızda da \% 2,7 oranında GİS kaynaklı GA tespit edilmiştir. Hastalarımızın tamamında gastroözefageal reflü tespit edilmiş olup ağızda acı tat hissi ve gece öksürüğü mevcuttu.

Psikiyatrik problemler de her türlü ağrı ile seyredebileceği için GA da yapabilir. Özellikle adölesan dönemde ve kızlarda daha fazla olmakla birlikte literatürdeki sıklığı \% 7-17 arasındadır (14). Çalışmalarda psikojenik GA sıklığı \% 5-11 oranında saptanmıştır $(15,16,17)$. Bizim çalışmamızda psikojenik GA olgularının çoğunluğu kız ve adölesan yaş grubundaydı. GA nedeniyle başvuran adölesan ve özellikle kız hastalarda psikojenik neden akılda bulundurulmalı ve bu hastalara daha fazla zaman ayırıp, iyi bir anamnez alınmalı, aile ve sosyal çevre ilişkileri ayrıntılı şekilde sorgulanmalıdır.

Kalpten kaynaklı sebepler GA'nın etyolojisinde çok az bir yeri kapsamaktadır. Çocuklarda kardiyak nedenli GA sıklığ $1 \%$ 0,7-5 arasındadır $(4,5)$. Kardiyak GA yapan en sık nedenler MVP, TY, MY, WPW, BAK, miyokardit, perikardit, pulmoner hipertansiyon, Kawasaki hastalığı, aritmiler, akut romatizmal ateştir $(7,10,13)$. Kardiyak kökenli nedenler nadirdir fakat ani ölüm riski taşırlar. Anamnezinde ailesinde erken yaşta ve ani ölüm öyküsü olan, fizik muayenesinde ve EKG'de anormallik olan olgular çocuk kardiyoloji ile görüşülerek EKO yapılması önerilmelidir $(2,10)$. Kardiyak nedenli gögüs ağrıları çoğunlukla prekordiyal bölgede hissedilmekle birlikte omuz, kol ve çeneye de yansıyabilir. Ayrıca göğüste basınç hissetme, baş dönmesi, çarpıntı, dispne veya senkop da eşlik edebilir $(8,13,18)$. Bizim çalışmamızda da kardiyak kökenli olgular \% 6 olarak saptanmış olup başka çalışmalarla benzerdi. Tanılarımız sıklık sırasına göre MVP, ASD, TY, MY, WPW, BAK'tı. Hastalara herhangi bir işlem yapılmamıș sadece poliklinik takibine alınmışlardı. GA şikayeti ile gelen hastalarda kardiyak marker olarak troponin, kreatin kinaz en sık kullanılan tetkiklerdir. Çalışmalarda troponin düzeylerinin yüksek oranda negatif olduğu saptanmış ve ciddi GA olmayan, EKG ve EKO'da patolojik bulguları olmayan hastalardan troponin tetkiki istemenin yararsız olduğu bildirilmiştir $(19,20)$. Bizim çalışmamızda da troponin düzeyi genel olarak normal seviyedeydi. Kardiyak ve nonkardiyak GA nedenleri ile CK, CKMB ve Troponin değerleri arasında istatistiksel olarak anlamlı bir farklılık saptanmadı. Bu yüzden eğer anamnez ve fizik muayene sonucunda organik bir patoloji düşünülmüyorsa gereksiz tetkiklerden kaçınılmalıdır. Çünkü aileler ve yakınları genellikle endişeli şekilde teşhisin belli olmasını beklemektedirler.

Çalışmamız retrospektif olduğu için ve acil servis kayıtlarındaki verilere göre bazı bilgiler (GA'nın karakteri, ne kadar süre GA varlığıl, gece gündüz ilişkisi, eforla ilişkisi gibi) elde edilememiştir. Bu durum çalışmamızın kısıtlayıcı yönüdür. Prospektif ve çok merkezli, daha ayrıntılı sonuçlar verebilecek çalışmalara ihtiyaç duyulmaktadır.

Sonuç olarak ailelerin ciddi şekilde huzursuz ve gergin olmasına neden olan kardiyak nedenli GA çocuklarda oldukça nadir görülmektedir. İyi alınmış anamnez, normal bir fizik muayene ve EKG'si olan hastalarda kardiyak patolojiler büyük oranda ekarte edilir. GA ani başlangıçl, göğüse basınç hissi veren, senkop eşlik eden, eforla artan, ve kişinin aile öyküsünde patoloji var ise bu olgulardan kardiyak patoloji düşünülerek çocuk kardiyoloji bölümünce değerlendirilmelidir. Hastaların çoğunluğunda kalp dışı bir neden olduğu için hasta ve ailesine bilgi verilerek rahatlamaları sağlanmalıdır.

Çalışmanın yapılmasında hiçbir kurum ve kuruluştan finansal destek alınmamıştır ve yazarlar arasında hiçbir şekilde çıkar çatışması yoktur.

\section{KAYNAKLAR}

1. Kocis KC. Chest pain in pediatrics. Pediatr Clin North Am 1999; 46: 189-203

2. Friedman KG, Alexander ME. Chest pain and syncope in children: A practical approach to the diagnosis of cardiac disease. J Pediatr 2013;163(3):896-901.

3. Ruigomez A, Rodriguez LA, Wallander MA, Johansson S, Jones R. Chest pain in general practice: incidence, comorbidity and mortality. Fam Pract 2006; 23: 167-74.

4. Driscoll DJ. Chest pain in children and adolescents. In: Allen HD, 
Driscoll DJ, Shaddy RE, Feltes TF (eds). Moss and Adams' heart disease in infants, children, and adolescents: including the fetus and young adult. 7th ed. Philadelphia, Lippincott Williams \&Wilkins, 2008; 1444-6.

5. Hanson CL, Hokanson JS. Etiology of chest pain in children and adolescents reffered to cardiology clinic. WMJ 2011; 11: 58-62.

6. Geggel RL. Conditions leading to pediatric cardiology consultation in a tertiary academic hospital. Pediatrics 2004; 114: 409-17.

7. Akalın F. Adölesanda göğüs ağrısına yaklaşım. Türk Pediatri Arşivi 2010;3(45):164-6.

8. Kervancıoğlu M, Devecioğlu C, Okur N. Çocuk kardiyoloji polikliniğine göğüs ağrısı yakınmasıyla başvuran hastaların değerlendirilmesi. Dicle Tip Derg 2005;32(4):196-200

9. Bostan ÖM. Çocuklarda ve adölesanlarda göğüs ağrısı. Güncel Pediatri Dergisi 2006;2:26-30.

10.Özbarlas N. Göğüs ağrlları. Güncel Pediatri Dergisi 2008;6(1):173-5.

11. Park MK. Kawasaki disease. Pediatric Cardıology for Practitioners. 5th ed. Philadelphia: Mosby Elsevier,2008:606-19.

12. Geggel R, Endom E. Non traumatic chest pain in children and adolescents:Approach and initial management. Avaiable from: https://www.uptodate.com/contents/nontraumatic chest pain in children and adolescents approach and initial management.

13.Tunaoğlu FS. Çocukluk çağı göğüs ağrıları. Sted 2003;12(2):53-6.

14. Anzai AK, Merkin TE. Adolescent chest pain. Am Fam Physician 1996;53:1682-8.

15.Tiryaki S, Kırlı U. Göğüs ağrısı ile çocuk kardiyoloji polikliniğine başvuran olguların epidemiyolojik, etyolojik ve klinik özellikleri. Türkiye Çocuk Hast Derg 2018;3:205-211

16. Güvenç O, Kaya F, Arslan D, Çimen D, Oran B. Göğüs Ağrısı Olan 441 Çocuk Hastanın Değerlendirilmesi. Selçuk Tıp Derg 2014;30(4): 159161.

17. Alp H ve Alp E. Çocuk kardiyoloji Kliniğine Göğüs ağrısı nedeniyle başvuran olguların etiyolojik değerlendirilmesi. The journal of Pediatric Research 2014;1:80-3.

18. Selbst SM. Approach to the child with chest pain. Pediatr Clin North Am 2010; 57: 1221-34.

19. Liesemer K, Casper TC, Korgenski K, Menon SC. Use and misuse of serum troponin assays in pediatric practice. Am J Cardiol 2012; 110 : 284-9.

20. Brown JL, Hirsh DA, Mahle WT. Use of troponin as a screen for chest pain in the pediatric emergency department. Pediatr Cardiol 2012; 33: $337-42$. 